\title{
Zmeny vybraných ukazovatelov motorickej a hernej výkonnosti elitných mladých futbalistov vplyvom herného tréningu
}

\section{Changes the selected indicators and the performance of the game's elite young soccer players from the motor of the game workouts}

\author{
Pavol Peráček, Jozef Záhorský
}

Fakulta telesnej výchovy a športu, Univerzita Komenského, Bratislava

\begin{abstract}
Abstrakt
Výskum je orientovaný na problematiku športovej prípravy mladých elitných futbalistov. Išlo o dvojskupinový, časovo súbežný pedagogický experiment v prirodzených podmienkach tréningového procesu. Zistovali sme vplyv experimentálneho činitela na dynamiku zmien hernej výkonnosti mladých elitných futbalistov. Experimentálnym činitelom $v$ našom pedagogickom experimente bol obsah tréningového procesu, akcentujúci špecifické tréningové podnety v priebehu ročného tréningového cyklu. Pri jeho koncipovaní sme vychádzali z premisy, že špecifické tréningové podnety vyvolajú špecifickú adaptáciu. Dosiahnuté výsledky hráčov experimentálneho súboru sme analyzovali a porovnali s výsledkami hráčov kontrolného súboru. Dospeli sme k záverom, že tréningový program experimentálneho súboru akcentujúci špecifické tréningové podnety ako východiskový bod zmeny herného výkonu tvorí komplexné pôsobenie, ktorého charakter ako požiadavka hry vyplýva z druhu tréningového zataženia. Tréningový program experimentálneho súboru mal štatisticky významný vplyv na zmeny výkonov hráčov experimentálneho súboru v oblasti špeciálnej motorickej výkonnosti, voči hráčom kontrolného súboru, ale aj na zmeny hernej výkonnosti, ktorá sa prejavila vo vyššej efektivite herných činností v sledovaných zápasoch (IHV) a v umiestnení družstva v sútaži (HVD).
\end{abstract}

\begin{abstract}
Research is oriented on the issue of sports training of young elite soccer players. It was a dvojskupinový, a parallel educational experiment in the natural conditions of the training process. We are exploring the impact of the experimental agent on the dynamics of the game changes the performance of the young elite footballers. The experimental factor in our pedagogical experiment was the content of the training process, accentuating specific training initiatives during the annual training cycle. In its conception, we are based on the premise that specific training stimuli can induce specific adaptation. The results obtained were analysed and compared with the results of the file we experimental players players the checkpoint file. We have reached the conclusion that the training program of the experimental training suggestions as a starting point the changes specific to accentuating the file of the game performance is a complex operation, whose nature as a requirement of the game stems from the nature of the training load. Training program had a statistically significant influence on changes to file experimental performances, the players in the field of special motor performance, to file the experimental gamers the checkpoint file, but also to change the gaming performance, which manifested itself in a higher efficiency of the gaming activities in the scheduled matches (IHV) and at the location of the cooperative in the contest (HVD).
\end{abstract}

Klúčové slová: futbal, elitní juniorskí hráči, herný tréning, motorická a herná výkonnost'.

Keywords: soccer, elite junior players, games training, motor and player performance.

Táto práca je súčastou projektu VEGA č.1/1252/12 - Zdokonalenie systému identifikácie a výberu talentovaných hráčov futbalu pre juniorské reprezentačné družstvá v SR a zefektívnenie obsahu ich prípravy. 


\section{Úvod}

V poslednom období sa vel'mi často stretávame s pojmom efektívnost̉ tréningového procesu. Miera efektívnosti športovej prípravy mladých futbalistov závisí od racionálneho využívania všetkých jej komponentov (ciel', obsah, interakcia tréner - hráč, uplatňované metódy, postupy, formy, podmienky) a od ich vzájomných vztahov, na základe ktorých tento proces prebieha. Efektívnost’ športového tréningu vo futbale by mala vyplývat z princípu vedeckosti, z dokonalého osvojenia a rozpracovania obsahu tréningového procesu. Z uvedeného chceme zvýraznit predovšetkým d’alšie rozpracovanie vedeckých základov riadenia tréningového procesu, kde pozornost by mala byṫ zameraná na optimalizáciu jednotlivých súčastí tréningového procesu z hladiska vytvárania dôležitých podmienok pre kvalitné riadenie stavu hráča od tréningových jednotiek až po etapy dlhodobej športovej prípravy. Kategória starších dorastencov patrí do etapy špeciálnej športovej prípravy, ktorá je zameraná na dosiahnutie športového majstrovstva cestou zdokonalenia tých stránok športovca, ktoré sú dôležité pre výkonnostnú finalizáciu športovej špecializácie. Cielom etapy špeciálnej športovej prípravy, ktorá nadväzuje na predchádzajúcu prípravu je d’alšie rozvíjanie a formovanie potenciálu herného výkonu pre potreby vrcholového futbalu (Peráček - Hucko, 2003). Peráček (1999) charakterizuje faktory, ktoré ovplyvňujú štrukturalizáciu obsahu hernej prípravy:

a) rešpektovanie biologických zvláštností organizmu, to znamená okrem morfologických, fyziologických a psychologických, aj d’alšie stránky vývoja organizmu,

b) dlhodobé a perspektívne zameranie a charakter tohto procesu na rozdiel od tréningu dospelých,

c) rôznorodost podmienok a prostriedkov, racionálne striedanie zataženia a oddychu, variabilita zataženia.

Pri zistovaní efektívnosti tréningového procesu však nestačí zistovat iba jeho výsledky a porovnat ich s požadovanými ciel'mi. Tvrdíme, že miera efektívnosti športovej prípravy mladých futbalistov závisí od racionálneho využívania všetkých jej komponentov (ciel', obsah, interakcia tréner - hráč, uplatňované metódy, postupy, formy, podmienky) a od ich vzájomných vzt’ahov, za ktorých tento proces prebieha (Peráček, 1992). Tréningové zataženie je realizované prostredníctvom účelovo zameraných pohybových aktivít, ktoré je možné chápat ako adaptačné podnety (trénovanost̉ je z toho pohladu zvláštnym typom adaptácie na pohybové zataženie), ktorých konkrétny obsah vychádza z požiadaviek zápasov na individuálny a tímový herný výkon hráčov (Buzek - Bunc, 1996). Inak povedané, $v$ športovom tréningu zámerne stimulujeme adaptačné procesy zodpovedajúce obsahovým požiadavkám štruktúry športového výkonu. Ako tvrdí Savelsbergh - Kamp (2001), v tréningu musíme využívat špecifické podnety tak často, ako sa len dá, ale nie vždy a za každú cenu.

Vlastná práca trénera spočíva vo vyhl'adávaní a zostavovaní vhodných kombinácií objemu zataženia, jej intenzity, frekvencie (Bangsbo, 2002; Hulse, 2003), ale musíme akceptovat aj zložitost’ pohybového a zručnostného obsahu (Buzek - Bunc, 1996; Reilly, 1994; Strudwick - Reilly, 2001; Reilly, 2002; Balsom, 2003; Reilly, 2003; Strudwick, 2003). V poslednom období sa preto vo futbale, objavujú nové prístupy k plánovaniu, stavbe a realizácii tréningového procesu. Podnetom pre vznik týchto nových koncepcií vo futbale je podla Peráčka (1999) práve požiadavka vykonávat všetko s loptou, ako aj snaha o objektívnejšie posúdenie tréningového zataženia.

\section{Ciel' práce}

Ciel'om nášho výskumu bolo zistit efektívnost' zvyšovania výkonnosti mladých elitných futbalistov $\mathrm{v}$ jednoročnom cykle športovej prípravy prostredníctvom racionalizácie tréningového procesu, ktorého rozhodujúcim činitel’om je tréningové zataženie v hernom tréningu. 


\section{Hlavná hypotéza}

Predpokladáme, že navrhovaný plán ročného tréningového cyklu športovej prípravy elitných mladých hráčov so špecifickým obsahovým zameraním s akcentom na herný tréning sa pozitívne prejaví v sledovaných ukazovatel’och motorickej výkonnosti, hernej výkonnosti a športovej úspešnosti experimentálneho súboru.

\section{Čiastkové hypotézy}

H1 Predpokladáme štatisticky významné zlepšenie výkonu experimentálnej skupiny vo všetkých testoch motorickej výkonnosti.

H 2 Predpokladáme, že vplyv experimentálneho činitel’a sa prejaví v štatisticky významných rozdieloch výkonov experimentálnej skupiny oproti kontrolnej skupine v testoch a kontrolnom cvičení špeciálnej motorickej výkonnosti.

H3 Predpokladáme, že v experimentálnej skupine zaznamenáme zvýšenie úspešnosti vo vybraných ukazovatel'och herného výkonu v sledovaných zápasových etapách.

\section{Metodika}

Dizajn výskumu

Išlo o dvojskupinový pedagogický experiment v prirodzených podmienkach tréningového procesu. Na základe relevantných (typických) znakov základného súboru sme pri určovaní kontrolného a experimentálneho súboru použili zámerný výber. Išlo o kvalifikovaný výber - kategória elitných mladých hráčov U 18.

Experimentálny súbor (VE) tvorili elitní mladí hráči klubu hrajúceho najvyššiu sútaž na Slovensku v svojej vekovej kategórii. Stabilný hráčsky káder tvorilo 17 futbalistov s priemerným vekom 16,9 rokov a s priemernou dobou aktívnej športovej činnosti 10,7 rokov na začiatku experimentu. Výškový priemer VE bol na začiatku experimentu 179,8 cm, hmotnostný $69,1 \mathrm{~kg}$. Z hladiska výkonnosti môžeme považovat VE za homogénny. Kontrolný súbor (VK) tvorili elitní mladí hráči klubu hrajúceho takú istú sútaž ako VE. Stabilný hráčsky káder VK prestavovalo 19 futbalistov s priemerným vekom 17,3 rokov a s priemernou dobou aktívnej športovej činnosti 10,8 rokov na začiatku experimentu. Výškový priemer VK bol na začiatku experimentu $182,4 \mathrm{~cm}$, hmotnostný $75,8 \mathrm{~kg}$.

Experimentálnym činitel’om bol obsah ročného tréningového cyklu (VE) s jeho racionálnou štruktúrou a adekvátnou dynamikou zataženia, ktorý efektívne pôsobil, vyvážene a systematicky stimuloval vybrané determinanty herného výkonu (VE) a v ktorom sme uplatňovali súčasné tendencie $\mathrm{v}$ športovej príprave mládeže vo futbale. V tréningovom procese VE sa to prejavilo dominantným zastúpením herného tréningu zo súčastí tréningového procesu. Experimentálny činitel' pravdepodobného charakteru teda $v$ priebehu experimentu akcentoval:

a) proporcionalitu súčastí tréningového procesu s vyšším zastúpením herného tréningu,

b) zvýšené zastúpenie špecifických zátažových herných činností v porovnaní s nešpecifickými kondičnými zátažovými činnostami,

Kontrolným činitel’om bol obsah ročného tréningového cyklu (pre VK), ktorý vychádzal z odporúčaných noriem základného programového materiálu (Kačáni - Peráček, 1989) pre danú vekovú kategóriu. Odporúčaná proporcionalita súčastí tréningového procesu elitných mladých hráčov v sledovanej vekovej kategórii, ktorej sme sa držali pri zostavovaní jednoročného tréningového procesu v kontrolnej skupine bola: 
- Herný nácvik - $40 \%$

- Herný tréning - $40 \%$

- Kondičný tréning - $20 \%$

\section{Proporcionalita súčastí TP v RTC}

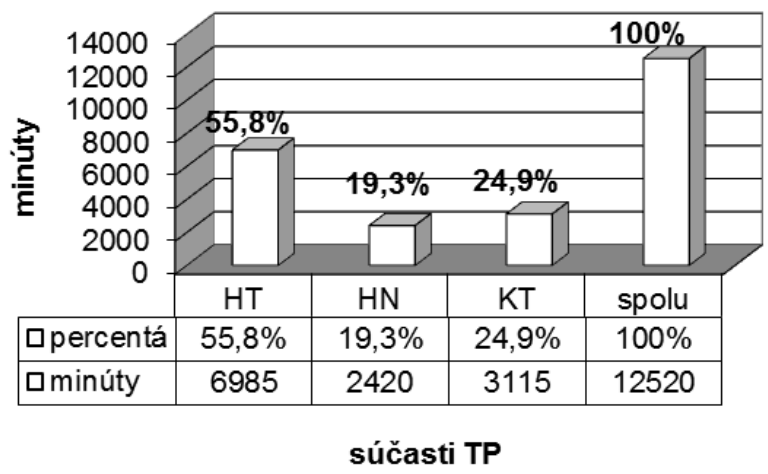

Obrázok 1 VE: Proporcionalita súčastí tréningového procesu v ročnom tréningovom cykle (\%, min).

Odporúčaná proporcionalita metodických foriem v jednoročnom tréningovom procese elitných mladých hráčov predstavovala nasledovné hodnoty:

- Prípravné cvičenia - $20 \%$

- Herné cvičenia - 30\%

- Prípravné hry a vlastná hra - 50\%

Porovnanie vybraných všeobecných tréningových ukazovatel’ov spojených so zápasmi medzi experimentálnym a kontrolným súborom v ročnom tréningovom cykle (počet, min).

\begin{tabular}{cccccccc}
\hline VTU & PZ & ZH & MZ & ČZ & RZ & KCZ & TPZ \\
\hline VE & 17 & 6 & 30 & 4340 & 1330 & 465 & 1155 \\
VK & 29 & 12 & 30 & 5500 & 605 & 605 & 1055
\end{tabular}

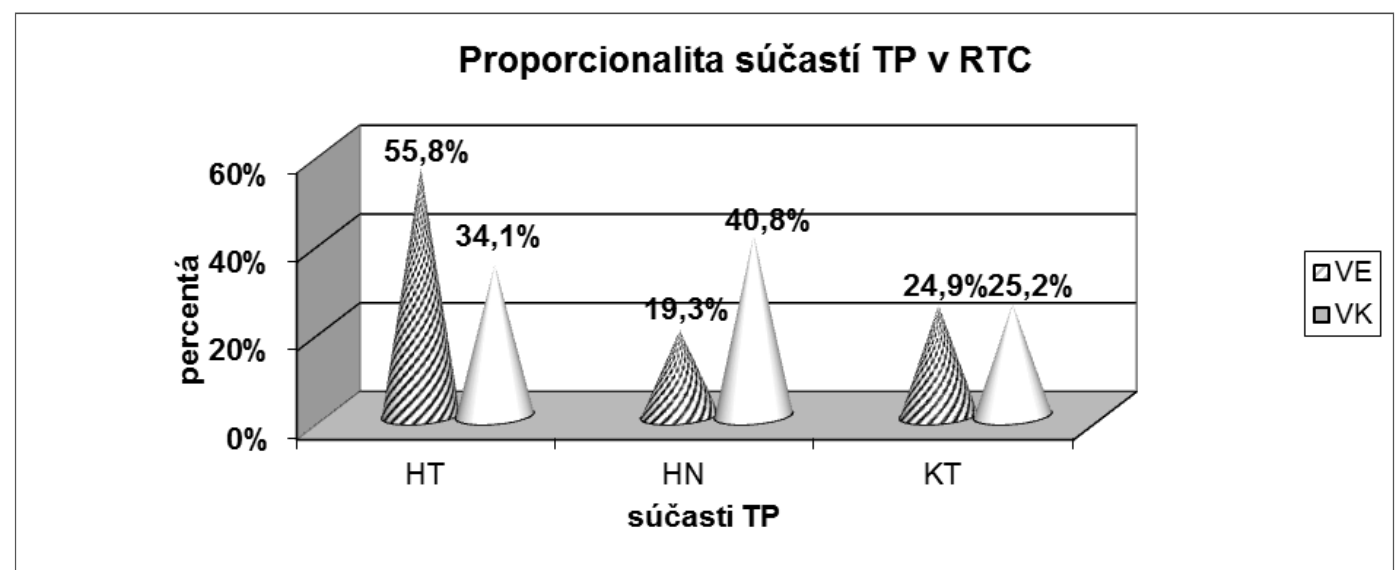

Obrázok 2 Proporcionalita súčastí tréningového procesu v ročnom tréningovom cykle v experimentálnej a v kontrolnej skupine (\%). 


\section{Výskumné údaje sme získavali z nasledovných oblastí}

\section{Stanovenie maximálnej spotreby kyslíka}

Funkčné ukazovatele $\mathrm{v}$ našom experimente pozostávali $\mathrm{z}$ testovania telesnej zdatnosti určením VO2max nepriamou metódou na základe výsledkov vo vytrvalostnom člnkovom behu. Vychádzali sme z poznania tesného korelačného vztahu k dosiahnutým výsledkom vo vytrvalostnom člnkovom behu. Po absolvovaní testu je možné zistit hodnoty maximálnej spotreby kyslíka na kilogram telesnej hmotnosti (Brewer et al., 1988; Moravec - Tománek, 2007 (podl'a Léger - Lambert, 1982; Léger - Gadoury, 1989)).

Všeobecná motorická výkonnost'

$\mathrm{Na}$ hodnotenie všeobecnej motorickej výkonnosti sme použili batériu nasledovných testov:

- Predklon v stoji na lavičke,

- Skok do dial'ky z miesta $(\mathrm{cm})$,

- Lah - sed (za 1 min, počet)

- Vytrvalostný člnkový beh

\section{Špeciálna motorická výkonnost’}

$\mathrm{Na}$ hodnotenie špeciálnej motorickej výkonnosti sme použili tri testy a jedno kontrolné cvičenie:

- Člnkový beh 5 x 10 metrov,

- Beh na 30 metrov,

- Prekážková dráha

- Slalom s loptou (kontrolné cvičenie).

Pri zostavovaní nami použitej batérie testov a kontrolných cvičení sme sa opierali o poznatky Blahuš (1976), Měkota - Blahuš (1983), Komadel - Hamar - Marček (1985), Moravec Kampmiller - Sedláček et al. (1996), Kačáni (2000, 2005). Testovanie výkonu v motorických testoch a v kontrolných cvičeniach bolo realizované 4-krát a prebiehalo v štandardných podmienkach na umelej tráve.

Vstupné meranie a testovanie: (Dt0) - Začiatok PO I - júl

Priebežné meranie 1: (Dt1) - Koniec HO I - november

Priebežné meranie 2: (Dt2) - Koniec PO II (resp. začiatok HO II) - marec

Výstupné meranie a testovanie: (Dt3) - Koniec HO II - jún

Predpokladáme, že v čase jednotlivých meraní nedošlo k podstatným zmenám v stavoch hráčov. Vychádzajúc z poznatkov Peráčka (1992), že vol'bou intervalov sme medzi meraniami a fixovaním poradia snímania údajov o jednotlivých stavoch u všetkých členov oboch výskumných súborov vylúčili vplyv jedného stavu na výsledky merania druhého stavu. Zároveň sme týmito opatreniami predchádzali skresleniu individuálneho kolísania stavov, ktoré by mohli nastat ako dôsledok merania (Havlíček, 1983).

Organizácia tréningových jednotiek určených na testovanie motorickej výkonnosti prebiehala vždy podl'a rovnakého časového harmonogramu.

Na zvýšenie objektívnosti hodnotenia intenzity značne špecifického tréningového zataženia sme v tréningovom procese využívali športtestery (Polar RS $300 \mathrm{X}$ ), pomocou ktorých sme zaznamenávali srdcovú frekvenciu hráčov v tréningovom procese - kalibrácia 5 sekúnd. Hráčom sme na začiatku prípravného obdobia I a prípravného obdobia II zistili maximálnu srdcovú frekvenciu a $\mathrm{z}$ nej vypočítali pásma tréningového zataženia. Na základe zistených hodnôt SFmax sme jednotlivým hráčom stanovili zátažové pásma, v ktorých sa „mali v tréningovom procese pohybovat" podl'a našich požiadaviek. SFmax sme u jednotlivých hráčov namerali pri terénnom teste vytrvalostný člnkový beh na 20 metrov do vyčerpania (Kovár̆, 1990). Pri stanovení intenzity tréningového zataženia zo srdcovej frekvencie sme vychádzali z poznatkov autorov Buzek - Bunc 
(1996), Psotta et al. (2006). Na spracovanie a vyhodnocovanie zistených údajov sme použili základné charakteristiky matematickej štatistiky a d’alšie testy štatistickej významnosti:

- neparametrický Wilcoxonov T-test pri sledovaní dynamiky zmien v rámci testovaných skupín v motorických testoch,

- neparametrický Man-Whitneyov U-test pri sledovaní dynamiky zmien medzi testovanými skupinami v motorických testoch.

\section{Výsledky práce}

V práci uvádzame výsledky hráčov experimentálnej skupiny (13) a hráčov kontrolnej skupiny(12), ktorí sa zúčastnili všetkých testovaní a meraní, a tvorili aj základ hráčskych kolektívov počas sútažného ročníka.

\section{Výsledky všeobecnej motorickej výkonnosti}

Stanovenie maximálnej spotreby kyslíka

Podl'a aritmetického priemeru dosiahnutých hodnôt maximálnej spotreby kyslíka $\mathrm{v}$ jednotlivých meraniach, môžeme povedat, že hráči experimentálnej skupiny sa zlepšovali v každom z meraní, ked' vo vstupnom meraní dosiahli $51,12 \mathrm{ml} \cdot \mathrm{kg}^{-1} \cdot \mathrm{min}^{-1}$ a vo výstupnom meraní $55,1 \mathrm{ml} \cdot \mathrm{kg}^{-1}$. $\min ^{-1}$. Tak isto zlepšenie môžeme vidiet aj v dosiahnutých minimálnych (45,8 v Dt0 a 50,2 v Dt3) a maximálnych hodnotách (57,1 v Dt0 a 59,8 v Dt3), ale aj v strednej hodnote (medián). Podla zmeny aritmetického priemeru dosiahnutých hodnôt maximálnej spotreby kyslíka v jednotlivých meraniach, môžeme povedat, že hráči kontrolnej skupiny sa zlepšili vo výstupnom meraní oproti vstupnému meraniu. Vo vstupnom meraní bola priemerná hodnota $50,52 \mathrm{ml} \cdot \mathrm{kg}^{-1} \cdot \mathrm{min}^{-1}$ a vo výstupnom meraní $53,28 \mathrm{ml} \cdot \mathrm{kg}^{-1} \cdot \mathrm{min}^{-1}$.

Tabulka 1: Hodnoty VO2max získané nepriamou metódou vo vstupnom a výstupnom meraní v experimentálnej a kontrolnej skupine (ml.kg-1.min-1)

\begin{tabular}{|l|c|c|c|c|}
\hline & VE & VE & VK & VK \\
\hline & Dt0 & Dt3 & Dt0 & Dt3 \\
\hline Aritmetický priemer & 51,12 & 55,10 & 50,52 & 53,28 \\
\hline Smerodajná odchýlka & 3,28 & 2,83 & 4,42 & 4,38 \\
\hline Medián & 50,80 & 54,80 & 50,15 & 52,90 \\
\hline Maximum & 57,1 & 59,8 & 57,6 & 61,7 \\
\hline Minimum & 45,8 & 50,2 & 44,5 & 47,4 \\
\hline Variačné rozpätie & 11,3 & 9,6 & 13,1 & 14,3 \\
\hline Počet & 13 & 13 & 12 & 12 \\
\hline
\end{tabular}

\section{Predklon v stoji}

V teste predklon v stoji na lavičke sme zaznamenali pri porovnaní priemerných hodnôt vo VE mierne zlepšenie medzi Dt0 a Dt1, ako aj medzi Dt0 a Dt3, a to z 10,54 cm na $11,92 \mathrm{~cm}$. Podobne aj vo VK sme zaznamenali pri porovnaní priemerných hodnôt mierne zlepšenie medzi Dt0 a Dt3, a to z $10 \mathrm{~cm}$ na $10,75 \mathrm{~cm}$. ( $\mathrm{p}=\mathrm{n} . \mathrm{s}$.$) .$

\section{Skok do dial'ky z miesta}

V skoku do dial'ky z miesta sme zaznamenali priebežné zlepšovanie priemerných hodnôt po každom testovaní. Pri porovnaní rozdielov dosiahnutých výsledkov v skoku do dial'ky z miesta $\mathrm{v}$ jednotlivých meraniach medzi experimentálnym a kontrolným súborom bola $\mathrm{p}=\mathrm{n}$. $\mathrm{s}$. 


\section{Lah - sed}

Hoci priemerné hodnoty, stredné hodnoty (medián), maximálne i minimálne výkony sa vo výstupných testoch oproti vstupným zlepšili v obidvoch súboroch, $\mathrm{p}=\mathrm{n}$. $\mathrm{s}$.

\section{Vytrvalostný člnkový beh}

Rozvoj vytrvalostných schopností v hernom tréningu prostredníctvom prípravných hier bol tažiskom športovej prípravy v experimentálnej skupine. V teste na zistovanie úrovne vytrvalostných schopností sme zaznamenali štatisticky významné zlepšenie $(\mathbf{p}<\mathbf{0 , 0 5})$ medzi vstupným (Dt0) a 2. priebežným testovaním (Dt2), ako aj medzi vstupným a výstupným testovaním $(\mathbf{p}<\mathbf{0 , 0 1})$. V tomto teste sme v kontrolnom súbore nezaznamenali štatisticky významné zlepšenie.

Pri porovnaní výstupných meraní medzi experimentálnou a kontrolnou skupinou sme nezaznamenali štatistickú významnost̉ rozdielov $\mathrm{p}=\mathrm{n}$. $\mathrm{s}$.

Tabulka 2: Vytrvalostný člnkový beh (počet úsekov)

\begin{tabular}{|l|c|c|c|c|}
\hline & VE & VE & VK & VK \\
\hline & Dt0 & Dt3 & Dt0 & Dt3 \\
\hline Aritmetický priemer & 104,00 & 113,42 & 105,92 & 119,54 \\
\hline Smerodajná odchýlka & 14,68 & 15,20 & 10,70 & 10,15 \\
\hline Medián & 102,50 & 112,50 & 105,00 & 119,00 \\
\hline Maximum & 128 & 144 & 126 & 136 \\
\hline Minimum & 85 & 93 & 89 & 102 \\
\hline Variačné rozpätie & 43 & 51 & 37 & 34 \\
\hline Počet & 12 & 12 & 13 & 13 \\
\hline
\end{tabular}

\section{Špeciálna motorická výkonnost'}

\section{Člnkový beh $5 \times 10$ metrov}

V člnkovom behu $5 \times 10$ metrov sme zaznamenali štatistické zlepšenie v VE medzi výsledkami v Dt0 a Dt1 (p < 0,05), medzi výsledkami v Dt2 a Dt3 $(\mathbf{p}<\mathbf{0 , 0 5})$, ako aj medzi výsledkami vo vstupnom a výstupnom meraní (p $<\mathbf{0 , 0 1})$.

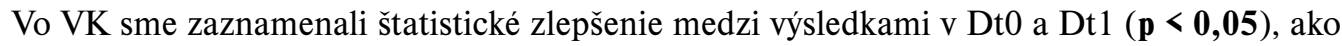
aj medzi výsledkami vo vstupnom a výstupnom meraní $(\mathbf{p}<\mathbf{0 , 0 1})$.

V teste člnkový beh 5x10 metrov sme pri porovnaní výstupných meraní medzi experimentálnou a kontrolnou skupinou zaznamenali štatistickú významnost̉ rozdielov $\mathrm{p}<0,10$.

Tabulka 3: Člnkový beh 5x10 metrov (sekundy)

\begin{tabular}{|l|c|c|c|c|}
\hline & VE & VE & VK & VK \\
\hline & Dt0 & Dt3 & Dt0 & Dt3 \\
\hline Aritmetický priemer & 11,82 & 11,31 & 11,93 & 11,10 \\
\hline Smerodajná odchýlka & 0,42 & 0,28 & 0,38 & 0,29 \\
\hline Medián & 11,70 & 11,37 & 11,97 & 11,07 \\
\hline Maximum & 12,50 & 11,68 & 12,40 & 11,66 \\
\hline Minimum & 11,38 & 10,73 & 11,22 & 10,68 \\
\hline Variačné rozpätie & 1,12 & 0,95 & 1,18 & 0,98 \\
\hline Počet & 12 & 12 & 13 & 13 \\
\hline
\end{tabular}

\section{Beh na 30 metrov}

Úroveň rýchlostných schopností sme zistovali testom beh na 30 metrov. Štatistické zlepšenie $(\mathbf{p}<\mathbf{0 , 0 5})$ sme zaznamenali medzi Dt2 a Dt3, ako aj medzi Dt0 a Dt3 vo VE.. Štatistické zlep- 
šenie (p < 0,05) sme v kontrolnom súbore VK zaznamenali medzi Dt0 a Dt1. V teste beh na 30 metrov sme pri porovnaní výstupných meraní medzi experimentálnou a kontrolnou skupinou nezaznamenali štatistickú významnost̉ rozdielov, $\mathrm{p}=$ n.s.

Tabulka 4: Beh na 30 metrov (sekundy)

\begin{tabular}{|l|c|c|c|c|}
\hline & VE & VE & VK & VK \\
\hline & Dt0 & Dt3 & Dt0 & Dt3 \\
\hline Aritmetický priemer & 4,17 & 4,05 & 4,11 & 4,08 \\
\hline Smerodajná odchýlka & 0,14 & 0,11 & 0,06 & 0,10 \\
\hline Medián & 4,12 & 4,04 & 4,11 & 4,07 \\
\hline Maximum & 4,45 & 4,22 & 4,22 & 4,24 \\
\hline Minimum & 3,95 & 3,89 & 3,98 & 3,98 \\
\hline Variačné rozpätie & 0,50 & 0,33 & 0,24 & 0,26 \\
\hline Počet & 12 & 12 & 12 & 12 \\
\hline & $\begin{array}{c}\text { Dt2 a Dt3: } \\
\mathbf{p}<\mathbf{0 , 0 5}\end{array}$ & & $\begin{array}{c}\text { Dt1 - Dt0: } \\
\mathbf{p}<\mathbf{0 , 0 5}\end{array}$ & \\
\hline
\end{tabular}

\section{Prekážková dráha}

Testom prekážková dráha sme zistovali úroveň koordinačných schopností. Štatistické zlepšenie $(\mathbf{p}<\mathbf{0 , 0 5})$ sme zaznamenali medzi Dt2 a Dt3, ako aj medzi Dt0 a Dt3(p $<\mathbf{0 , 0 5})$ v experimentálnom súbore VE. Experimentálny súbor sa oproti ostatným meraniam výrazne zlepšil vo výstupnom meraní. Štatistické zlepšenie $(\mathbf{p}<\mathbf{0 , 0 5})$ v kontrolnom súbore VK sme zaznamenali tiež medzi Dt2 a Dt3, ako aj medzi Dt0 a Dt3 (p $<\mathbf{0 , 0 1 )}$. V tomto teste sme pri porovnaní výstupných meraní medzi experimentálnou a kontrolnou skupinou zaznamenali štatistickú významnost’ rozdielov p $<0,05$.

Tabulka 5: Prekážková dráha (sekundy)

\begin{tabular}{|l|c|c|c|c|}
\hline & VE & VE & VK & VK \\
\hline & Dt0 & Dt3 & Dt0 & Dt3 \\
\hline Aritmetický priemer & 18,29 & 17,74 & 17,99 & 17,11 \\
\hline Smerodajná odchýlka & 1,16 & 0,45 & 0,84 & 0,73 \\
\hline Medián & 18,02 & 17,74 & 17,91 & 17,28 \\
\hline Maximum & 20,37 & 18,47 & 19,34 & 18,62 \\
\hline Minimum & 16,22 & 16,87 & 16,84 & 16,05 \\
\hline & $\begin{array}{c}\text { Dt2 a Dt3: } \\
\text { p }<\mathbf{0 , 0 5}\end{array}$ & $\begin{array}{c}\text { Dt0 a Dt3: } \\
\mathbf{p}<\mathbf{0 , 0 5}\end{array}$ & $\begin{array}{c}\text { Dt2 a Dt3: } \\
\mathbf{p}<\mathbf{0 , 0 5}\end{array}$ & $\begin{array}{c}\text { Dt0 a Dt3: } \\
\mathbf{p}<\mathbf{0 , 0 1}\end{array}$ \\
\hline
\end{tabular}

\section{Slalom s loptou}

V kontrolnom cvičení špeciálnej motorickej výkonnosti, slalom s loptou, sme v VE zaznamenali štatisticky významné zlepšenie medzi Dt2 a Dt3 $(\mathbf{p}<\mathbf{0 , 0 5})$ a medzi Dt0 a Dt3 $(\mathbf{p}<\mathbf{0 , 0 1})$. V kontrolnom cvičení, slalom s loptou, sme v VK zaznamenali štatisticky významné zlepšenie medzi Dt2 a Dt3 $(\mathbf{p}<\mathbf{0 , 0 5})$. V kontrolnom cvičení slalom s loptou sme pri porovnaní výstupných meraní medzi VE a VK zaznamenali štatistickú významnost̉ rozdielov p $<\mathbf{0 , 0 1}$. 
Tabulka 6: Slalom s loptou - hodnoty vstupného a výstupného merania v kontrolnej a experimentálnej skupine (sekundy)

\begin{tabular}{|l|c|c|c|c|}
\hline & VE & VE & VK & VK \\
\hline & Dt0 & Dt3 & Dt0 & Dt3 \\
\hline Aritmetický priemer & 19,10 & 19,17 & 19,36 & 17,97 \\
\hline Smerodajná odchýlka & 0,74 & 1,02 & 1,04 & 0,76 \\
\hline Medián & 18,99 & 19,43 & 19,38 & 17,91 \\
\hline Maximum & 20,66 & 20,63 & 21,63 & 19,29 \\
\hline Minimum & 18,22 & 17,54 & 17,25 & 16,86 \\
\hline Variačné rozpätie & 2,44 & 3,09 & 4,38 & 2,43 \\
\hline Počet & 12 & 12 & 13 & 13 \\
\hline
\end{tabular}

\section{Herný výkon jednotlivca vo vybraných ukazovateloch}

Hodnotenie herného výkonu v zápase Peráček (1990) podl’a Thies et al. (1978) rozumie pod diagnostikou výkonnosti „zistovanie aktuálnej výkonnosti formou získavania, hodnotenia a vyhodnocovania parametrov určujúcich výkonnost“". Pri zostavovaní kritérii na hodnotenie herného výkonu jednotlivca sme využili kombináciu viacerých doteraz využívaných metód (Korček, 1983; Hucko, 1986, 2003a, 2003b; Kačáni - Peráček, 1989; Kačáni, 1991; Kačáni - Peráček - Holienka, 1993; Tarkovič 1998; Kačáni, 2000, 2005). Vybrané ukazovatele herného výkonu sme sledovali vo vzájomných zápasoch VE a VK, ktoré sa odohrali v 11. kole a v 26. kole v sledovanej sezóne v sútaži, ktorú obidve družstvá hrali. Ked’že futbalová sezóna na Slovensku je rozdelená na jesennú a jarnú čast', rozhodli sme sa sledovat vybrané ukazovatele aj v prvých troch zápasoch (1. - 3. kolo) jesennej časti (Etapa A) a posledných troch zápasoch (13. - 15. kolo) jesennej časti (Etapa B) a v prvých troch zápasoch (Etapa C) a posledných troch zápasoch (Etapa D) jarnej časti (16. - 18. kolo a 28. - 30. kolo) sledovaného sútažného ročníka v experimentálnej aj v kontrolnej skupine. Tým sme sledovali motorickú výkonnost̉ a hernú výkonnost̉ približne v rovnakom čase.

$\mathrm{Z}$ metód na hodnotenie herného výkonu jednotlivca sme si zvolili metódu zámerného nepriameho (na základe dvd záznamu) pozorovania spojenú s metódou záznamu.

Pomocou zámerného nepriameho pozorovania spojeného s metódou záznamu sme hodnotili vybrané ukazovatele herného výkonu na základe aktivity hráčov vo vybraných herných činnostiach počas celého stretnutia, ako aj kvality vykonávaných herných činností. Pomocou štatistického záznamu sme evidovali herný výkon jednotlivca vo vybraných ukazovatel’och:

- početnost̉ a úspešnost̉ odoberania lopty,

- početnosṫ a úspešnost̉ hlavičkových súbojov,

- početnost̉ a úspešnost̉ obchádzania súpera,

- početnost' a úspešnosṫ finálnych prihrávok,

- početnost̉ a úspešnost̉ streleckých pokusov.

Početnost' a kvalitu vybraných ukazovatel'ov herného výkonu sme zaznamenávali do pripravených záznamových hárkov. V práci sme použili jednoznačné hodnotenie herných činností (+ / -). Znamienkom „,“ sme označili úspešnú, presnú hernú činnost’ a znamienkom „-“ sme označili neúspešnú, nepresnú hernú činnost'. Počet kladných a záporných znamienok sme sčítali a vyjadrili percentom úspešnosti celého družstva vo vybraných ukazovatel'och. Úspešnost jednotlivých družstiev (experimentálneho a kontrolného súboru) v sledovaných ukazovatel’och herného výkonu sme potom porovnávali v rámci jednotlivých zápasových etáp. 


\section{Odoberanie lopty}

Pri hodnotení odoberania lopty môžeme konštatovat', že úspešnost̉ tejto sledovanej hernej činnosti hráčov VE bola v každej sledovanej etape viac ako $60 \%$. Najväčšia bola $v$ zápasoch etapy D (76,5\%). Osobné súboje z pohladu obrannej fázy hry v každej sledovanej etape presahovali počet 240, pričom najviac ich bolo v zápasoch etapy C (256).

Tabulka 7: Porovnanie experimentálnej a kontrolnej skupiny v ukazovateli herného výkonu odoberanie lopty (počet, \%)

\begin{tabular}{|l|c|c|c|}
\hline & Odoberanie lopty & Úspešnost & Celkový počet \\
\hline ETAPA A & VE & $68,20 \%$ & 242 \\
\hline ETAPA A & VK & $65,20 \%$ & 253 \\
\hline ETAPA B & VE & $63,70 \%$ & 248 \\
\hline ETAPA B & VK & $72,30 \%$ & 267 \\
\hline ETAPA C & VE & $67,20 \%$ & 256 \\
\hline ETAPA C & VK & $72,40 \%$ & 243 \\
\hline ETAPA D & VE & $76,50 \%$ & 247 \\
\hline ETAPA D & VK & $73,20 \%$ & 272 \\
\hline
\end{tabular}

\section{Hlavičkové súboje}

Úspešnosṫ hlavičkových súbojov bola vo VK v sledovaných zápasoch každej etapy viac ako $70 \%$. Kontrolná skupina si najlepšie počínala v zápasoch etapy B (80,2\%). Naopak experimentálna skupina si najlepšie počínala v tomto ukazovateli $\mathrm{HV} v$ zápasoch etapy $\mathrm{D}$, ked' úspešnost' dosiahla úroveň $78,2 \%$. Najmenší počet hlavičkových súbojov (272) sme vo VK zaznamenali v zápasoch etapy $\mathrm{C}$, naopak najvyšší v zápasoch etapy D (rovnako ako vo VE).

Tabulka 8: Porovnanie experimentálnej a kontrolnej skupiny v ukazovateli herného výkonu hlavičkové súboje (počet, \%)

\begin{tabular}{|l|c|c|c|}
\hline & Odoberanie lopty & Úspešnost' & Celkový počet \\
\hline ETAPA A & VE & $66,30 \%$ & 282 \\
\hline ETAPA A & VK & $73,40 \%$ & 301 \\
\hline ETAPA B & VE & $70,80 \%$ & 284 \\
\hline ETAPA B & VK & $80,20 \%$ & 298 \\
\hline ETAPA C & VE & $72,80 \%$ & 272 \\
\hline ETAPA C & VK & $74,70 \%$ & 285 \\
\hline ETAPA D & VE & $78,20 \%$ & 293 \\
\hline ETAPA D & VK & $76,30 \%$ & 308 \\
\hline
\end{tabular}

\section{Obchádzanie súpera}

O obchádzanie súpera sa hráči experimentálnej skupiny pokúšali najviac v zápasoch etapy D, a to 213-krát. V tejto etape boli aj najúspešnejší - 68,1\%. Naopak najmenej sa o obchádzanie pokúšali v zápasoch etapy A a boli pritom aj najmenej úspešní $(59,9 \%)$. Pozitívom je, že úspešnost' obchádzania súpera v každej etape stúpala. 
Tabulka 9: Porovnanie experimentálnej a kontrolnej skupiny v ukazovateli herného výkonu obchádzanie súpera (počet, \%)

\begin{tabular}{|l|c|c|c|}
\hline & Odoberanie lopty & Úspešnost' & Celkový počet \\
\hline ETAPA A & VE & $59,90 \%$ & 187 \\
\hline ETAPA A & VK & $66,80 \%$ & 199 \\
\hline ETAPA B & VE & $60 \%$ & 205 \\
\hline ETAPA B & VK & $60,50 \%$ & 228 \\
\hline ETAPA C & VE & $63,40 \%$ & 202 \\
\hline ETAPA C & VK & $65,40 \%$ & 217 \\
\hline ETAPA D & VE & $68,10 \%$ & 213 \\
\hline ETAPA D & VK & $66,70 \%$ & 231 \\
\hline
\end{tabular}

\section{Finálne prihrávky}

Hráči experimentálneho súboru dali najviac finálnych prihrávok v zápasoch etapy D (123). V zápasoch etapy D mali aj najvyššiu úspešnost̉ - 39\%. V sledovaných zápasoch jednotlivých etáp stúpal aj počet presných finálnych prihrávok: $26-29-33-48$. Opät sa nám potvrdilo, že experimentálny súbor bol v útočnej fáze aktívnejší v jarnej časti sútaže oproti jesennej časti sútaže. So zvyšujúcou početnostou stúpala aj úspešnost̉ vykonávania herných činností.

Tabulka 10: Porovnanie experimentálnej a kontrolnej skupiny v ukazovateli herného výkonu finálne prihrávky (počet, \%)

\begin{tabular}{|l|c|c|c|}
\hline & Odoberanie lopty & Úspešnost' & Celkový počet \\
\hline ETAPA A & VE & $28,6 \%$ & 91 \\
\hline ETAPA A & VK & $33,3 \%$ & 96 \\
\hline ETAPA B & VE & $29,6 \%$ & 98 \\
\hline ETAPA B & VK & $35,7 \%$ & 98 \\
\hline ETAPA C & VE & $30,6 \%$ & 108 \\
\hline ETAPA C & VK & $34,7 \%$ & 95 \\
\hline ETAPA D & VE & $39 \%$ & 123 \\
\hline ETAPA D & VK & $36,6 \%$ & 112 \\
\hline
\end{tabular}

\section{Strel'ba}

Počet streleckých pokusov súboru VE sa zvyšoval v zápasoch každej etapy. V zápasoch etapy A to bolo 33 streleckých pokusov, z čoho padli 2 góly (6,1\%). V zápasoch etapy B strelilo družstvo experimentálneho súboru z 37 striel 7 gólov, čo predstavovalo úspešnosṫ $18,9 \%$. V zápasoch etapy C bola strelecká úspešnost menšia (14,3 \%), ked’ z 42 striel strelili hráči experimentálneho súboru 6 gólov. Nakoniec v zápasoch etapy D padlo najviac gólov - 11, čo predstavovalo v priemere 3,7 strelených gólov na zápas, pri celkovej úspešnosti $20 \%$.

V sledovaných zápasových etapách sme hodnotili herný výkon (HV) na základe aktivity hráčov vo vybraných ukazovatel'och HV, ako aj kvality ich vykonávania počas celého stretnutia.

Výsledky kontrolnej a experimentálnej skupiny sa výrazne nelíšili v celkovej početnosti vykonávania vybraných ukazovatel’ov HV. Predpokladali sme výraznejšie zlepšenie výkonu experimentálnej skupiny oproti kontrolnej skupine vo vybraných ukazovatel'och herného výkonu v sledovaných zápasových etapách. Kontrolný súbor dosahoval vyššiu úspešnost’ vo vybraných ukazovateloch HV v prvej časti sútaže (etapy A a B). Experimentálny súbor bol však v zápasoch poslednej etapy D úspešnejší vo všetkých sledovaných ukazovatel'och HV. 


\section{Hodnotenie športovej úspešnosti družstva v sútaži}

Ked’že sme hodnotili vybrané ukazovatele herného výkonu v zápasových etapách A, B, C, D, sledovaného sútažného ročníka hodnotili a porovnávali sme v týchto etapách aj športovú úspešnosṫ družstva na základe dosiahnutých výsledkov v sútaži. Navyše hodnotíme a porovnávame úspešnost’ experimentálnej skupiny na základe získaných bodov, dosiahnutého skóre a umiestnenia v tabul'ke po jesennej a jarnej časti sútaže. Na hodnotenie športovej úspešnosti sledovaného súboru sme použili výsledky jednotlivých majstrovských zápasov a umiestnenie družstva v sútaži. Vo futbale v kategórii elitných mladých hráčov sú tieto parametre všeobecne považované za jedny z hlavných kritérií úspešnosti družstva a ich výpovedná hodnota vcelku objektívne poukazuje na úroveň herného výkonu.

V priebežnej tabul'ke po jesennej časti sútaže patrilo experimentálnemu súboru zo 16 účastníkov až 11. miesto, po skončení jarnej časti obsadilo družstvo 3. miesto, ked’ na jeseň získalo 19 bodov a na jar 28 bodov, spolu 47 bodov. Kontrolný súbor bol po jesennej časti na 2 . mieste so ziskom bodov po jeseni 28 . V jarnej časti získal kontrolný súbor 33 bodov, spolu 61 bodov.

\section{Diskusia}

Naše skúsenosti s realizáciou dlhodobej športovej prípravy v praxi hovoria, že chýba práve spomínaná nadväznost’ - kontinuálnost prípravy a plynulost̉ prechodu hráčov z jednej etapy do druhej. Na tento problém poukazujeme vo viacerých literárnych prameňoch tak starších (Korček, 1976; Kačáni, 1978, 1980; Peráček - Kučera, 1984; Šajben - Peráček, 1984; Kačáni - Moravec - Peráček, 1989; Kačáni - Peráček, 1989; Peráček, 1989; Peráček, 1994), ako aj novších (Kačáni, 2000, 2005; Peráček, 2002a, 2002b; Peráček - Hucko, 2003, Peráček a kol.,2012). Za jeden $\mathrm{z}$ d’alších klúčových problémov súčasného nepriaznivého stavu nášho futbalu považujeme aj nízku úroveň a efektívnost̉ tréningového procesu, najmä v mládežníckych kategóriách. Chýba kvalitné plánovanie, evidencia tréningového zataženia (nie je spätná väzba), adekvátne venovanie sa rozvoju teoretických poznatkov hráčov (teoretická príprava) . Jednotlivé súčasti tréningového procesu (KT, HT, HN) sa plánujú izolovane. V tréningovom procese sa málo priestoru venuje hernému tréningu, čím nedochádza $\mathrm{k}$ špecifickej adaptácii hráčov. Na druhej strane je v tréningu mládeže vel’a herného nácviku a kondičného tréningu. V kondičnom tréningu dominuje hlavne rozvoj všeobecnej (aeróbnej) vytrvalosti a sily, pričom na rozvoj všetkých prejavov rýchlostných a koordinačných schopností sa zabúda. Nedostatky vyplývajú z nekoncepčnosti a nedôslednosti plánovania a realizácie tréningového procesu elitných mladých hráčov. Tréningový proces by mal smerovat najmä $\mathrm{k}$ vytvoreniu potrebných pohybových a technicko - taktických základov pre d’alšiu výkonnost̉ mladých hráčov. Pri posudzovaní tréningového zataženia a motorickej výkonnosti sme v práci uplatňovali predovšetkým ukazovatele, ktoré boli určené pokynmi na evidenciu tréningového zataženia v systéme elitného mládežníckeho futbalu na Slovensku. Osobitne pre útvary talentovanej mládeže je takáto evidencia tréningového zataženia záväzná. Evidencia tréningovej činnosti je neodmyslitel’nou požiadavkou pre plánovaný a racionálny tréningový proces. Ale tréningový plán a hlavne reálny tréningový proces bez jeho evidencie stráca zmysel. V našom výskume bola dôkladne vedená evidencia tréningového zataženia základom pre získanie spätnej väzby a následnej korekcie tréningu s ciel’om zvyšovania trénovanosti a výkonnosti hráčov. Musíme zdôraznit, že nešlo len o deskriptívny kvantitatívny zápis zatažovania, ale predovšetkým o vyhodnotenie a prenos získaných poznatkov do tréningového procesu a zápasu (Fajfer, 2005). Ak má herný tréning spíňat svoju charakteristiku, musí byt rozvíjaný nielen zručnostný potenciál hráčov, ale aj ich zdatnostný potenciál. Aby bol zabezpečený rozvoj zdatnostného potenciálu hráčov, muselo zataženie $v$ tréningu spíňat nami stanovenú intenzitu, ktorá vždy vychádzala $\mathrm{z}$ ciel’a a zamerania cvičenia, hry, resp. tréningovej jednotky. Tréneri niekedy vstupovali do tréningu, aby opravili hráčov, upozornili ich na chyby, korigovali ich činnost’ a pod. Museli sme však zabezpečit, aby 
častým, opakovaným alebo dlhým vstupovaním trénera do priebehu cvičenia, resp. hry neklesla intenzita zataženia do takej miery, že tréning prestával spĺn̆at atribúty herného tréningu.

Vnútornú reakciu organizmu hráčov na vonkajšie zataženie (podobne uvádzajú vo svojich prácach Kačáni 1981, 1982, 1999; Reilly, 1994; Bunc - Buzek, 1996; Weineck, 1997; Arcelli Ferretti, 1998; Pereni - Cesare, 1998; Psotta, 2006, Reilly, 2001, 2002, 2003; Strudwick - Reilly, 2001; Bangsbo, 2002; Balsom, 2003; Strudwick, 2003; a iní) sme sledovali monitorovaním srdcovej frekvencie športtestermi Polar RS 300 X. Rast výkonnosti hráča je v podstate procesom adaptácie, procesom morfologickej a funkčnej prestavby organizmu hráča $\mathrm{v}$ zmysle prispôsobenia sa požiadavkám daného herného výkonu. Tieto požiadavky musia byt’ kvantifikované pokial' možno čo najpresnejšie, čo umožňuje exaktné porovnanie zadaných požiadaviek so skutočne vykonanou tréningovou prácou za účelom zlepšenia výkonu. Iba týmto spôsobom je možné posúdit efektivitu tréningového procesu a iba takto sa môžu akceptovat dôležité modifikácie a získané poznatky o tréningovom zatažení (Peráček, 1995b). Preto sú aj viaceré súčasné výskumy zamerané na hladanie modelu zataženia hráča $v$ rôznych vekových kategóriách vo futbale (Peráček, 2002a; Peráček - Nincz, 2012).

V našej praxi sú často použivané modely tréningového zataženia, ktoré sú preberané jednotlivými trénermi bez toho, aby vychádzali z objektívnych charakteristík týchto modelov (Buzek - Bunc, 1996). Preto je vo svete i u nás neustále stupňované úsilie o vytvorenie „zásobárni“ overených tréningových cvičení a vyššie spomínaných modelov, z ktorých by tréner mohol zostavovat vlastné tréningové programy použitel’né u jeho hráčov. Dostatočná aeróbna výkonnost' je podmienkou na absolvovanie intenzívneho a kvalitného tréningového programu. Aj čast' charakteristiky futbalu, z pohl'adu zataženia hráča v zápase, vychádza $\mathrm{z}$ adekvátneho aeróbneho základu futbalistov a nepriamo tak ovplyvňuje efektivitu tréningu pri zdokonal'ovaní herných zručností (Peráček, 1995b; Psotta et al., 2006). Avšak pre objektívne posúdenie tréningového zataženia je potrebné presne vyjadrit úroveň a hodnotu zataženia použitých prostriedkov. Meranie srdcovej frekvencie nám dalo určitý obraz o odozve organizmu hráčov na tréningové zataženie. Takáto objektivizácia tréningového zataženia pomocou športtesterov nám umožnila začlenit hráčov do skupín pohybovej výkonnosti z hl’adiska pohybového potenciálu (Peráček, 1995b).

\section{Zhrnutie poznatkov}

Ciel'om nášho výskumu bolo $v$ jednoročnom cykle športovej prípravy elitných mladých hráčov vo futbale zistił efektívnosṫ zvyšovania výkonnosti elitných mladých futbalistov prostredníctvom racionalizácie tréningového procesu, ktorého rozhodujúcim činitel’om bolo tréningové zataženie v hernom tréningu. Na základe realizácie pedagogického experimentu v prirodzených podmienkach sme dospeli k nasledovným poznatkom:

1. Potvrdili sme možnost realizovat v praxi plán ročného tréningového cyklu športovej prípravy starších dorastencov vo futbale s akcentom na herný tréning. Vplyvom realizovaného tréningového zataženia nastali pozitívne zmeny vo všetkých sledovaných ukazovateloch motorickej a hernej výkonnosti experimentálneho súboru (Hlavná hypotéza).

2. Dynamika rastu motorickej výkonnosti v experimentálnej skupine potvrdila náš predpoklad pozitívneho vplyvu experimentálneho činitel'a na výkonnost̉ v experimentálnej skupiny, ktorá sa prejavila vo výsledkoch testov všeobecnej a špeciálnej motorickej výkonnosti.

3. Nepotvrdil sa náš predpoklad vplyvu experimentálneho činitel'a na výkonnost’ experimentálnej skupiny v porovnaní s kontrolnou skupinou vo všetkých testoch špeciálnej motorickej výkonnosti (H 1). Štatisticky významné rozdiely sme zaznamenali v troch zo štyroch testov špeciálnej motorickej výkonnosti, $v$ testoch člnkový beh $5 \times 10$ metrov $(\mathrm{p}<0,10)$, prekážková dráha $(\mathrm{p}<0,05)$ a slalom s loptou $(\mathrm{p}<0,01)$ ( $\mathrm{H} 2)$.

Pri porovnaní úrovne motorickej výkonnosti a umiestnenia družstiev dosiahnutých v sútaži sa ukazuje, že iba kondičná pripravenost̉ nie je dostatočnou zárukou zvládnutia futbalovej hry 
a úspechu v sútaži. Motorická výkonnosṫ kondičného charakteru je len potenciálnym predpokladom a efektívna je iba vtedy, ak sa uplatňuje v herných činnostiach (potvrdená $\mathrm{H} 3$ ).

Experimentálny súbor sa významne zlepšil vo všetkých sledovaných herných činnostiach v jednotlivých etapách výskumu. Získané výsledky v testoch všeobecnej a špeciálnej motorickej výkonnosti sami o sebe nezobrazujú špeciálnu pripravenost̉ elitných mladých hráčov. V našej práci sme overili vhodnost použitých špecifických prostriedkov pre danú vekovú kategóriu, ktorým sa často krát nevenuje primeraná pozornost̉ v praxi.

\section{Literatúra}

ARCELLI, E., \& FERRETTI, F. 1998. Fussball - Konditionstraining. Die aerobe und laktacide Ausdauer im Amateur- und Profifussballspieler. Leer: BFP Versand Anton Lindemann, 1998. $134 \mathrm{~s}$.

BALSOM, P. 2003. Monitoring Training Intensity in Football. In: Insight. The F.A. Coaches Association Journal. Issue 3. Volume 6. London: The Football Association, Summer 2003. s. 48

BANGSBO, J. 2002. The Physiological Preparation of Elite Players. In: Insight. The F.A. Coaches Association Journal. Issue 2. Volume 5. London: The Football Association, Spring 2002. s. 23-25.

BEARE, H., CALDWELL, B. J., \& MILLIKAN, R. S1989. Creating an Excellent School. London and New York: Routledge, 1989.

BLAHUŠ, P. 1976. Teoretické základy testování ve sportu. Praha: ÚV ČST, 1976. 134 s.

BREWER, J. et al. 1988. Multistage Fitness Test. In: A progressive Shutlle - run Test of the Prediction of Maximum Oxygen Uptake. Leeds: National Couching Foundation. Loughborough University, 1988. s. 18 - 20.

BUZEK, M. \& BUNC, V. 1996. Objektivizace tréninkových zátěží v herním tréninku. In: Fotbal a trénink. 5. Praha: ÚČFT, 1996. S. $14-18.22 \mathrm{~s}$.

FAJFER, Z. 2005. Tréner fotbalu mládeže (6 - 15 let). Praha: Olympia, 2005. 152 s. ISBN 80-7033-933-0

HAVLÍČEK, I. et al. 1987. Športová príprava talentovanej mládeže.In. Zborník Vedecko-metodickej rady SÚV ČSZTV, XIII. Bratislava: Šport, STVV, 1987. $332 \mathrm{~s}$.

HUCKO, J. 1986. Hodnotenie aktivity a kvality herného prejavu hráčov ČSSR „A“ vo futbale. In: Tréner, č. 2. Bratislava: SFZ, 1986.

HUCKO, J. 2003. Diagnostika individuálneho herného výkonu IHV. Hodnotenie herného výkonu a aktivity hráča na základe najdôležitejších herných činností. In: Profutbal. č. 2. Bratislava: SFZ, ÚFTS, 2003a. s. 3-12. 52 s.

HUCKO, J. 2003. IHV (individuálny herný výkon) hráčov našej ligy, reprezentácie Slovenska a niektorých hráčov LM. In: Profutbal. č. 3. Bratislava: SFZ, ÚFTS, 2003b. s. $14-21.52$ s.

HULSE, M. 2003. Physical and Physiological Characteristics of Elite Youth Football Players. In: Insight. The F.A. Coaches Association Journal. Issue 3. Volume 6. London: The Football Association, Summer 2003. s. 20-21

KAČÁNI, L., MORAVEC, M. \& PERÁČEK, P. 1989. Základný programový materiál výkonnostného futbalu mládeže a dospelých. Bratislava: Šport, 1989. 104 s..

KAČÁNI, L. \& PERÁČEK, P. 1989. Aktuálne problémy hernej prípravy futbalistov. Bratislava: SÚV ČSZTV, 1989. $161 \mathrm{s.}$

KAČÁNI, L., PERÁČEK, P. \& HOLIENKA, M. 1993. Motorická diagnostika vo futbale. Záverečná správa výskumu. Bratislava: FTVŠ UK, Katedra hier. 1993.

KAČÁNI, L. 2000. Futbal. Teória a prax hernej prípravy. Bratislava: SPN, 2000. 143 s. ISBN 80-08-03164-6

KAČÁNI, L. 2005. Futbal. Herná príprava (2) teória a prax. 2. Vydanie. Bratislava: SFZ, Krakora design, 2005. 228 s. ISBN 80969091-3-4

KORČEK, F. 1988. Súčasné tendencie športovej prípravy mládež. In: Skvalitnenie športovej prípravy mladých futbalistov. Metodické listy č. 6. Bratislava: VFZ SúV ČSZTV, 1988.

LÉGER, L. A. \& LAMBERT, O. A. 1982. A maximal multistage 20-m shuttle run test to predict VO2max. Europ. J. App. Physiol. 49, 1982. s. 1-12. In: MORAVEC, R. \& TOMÁNEK, Ĺ.: Závislost' výkonnosti vo vytrvalostnom člnkovom behu od podielu srdcovej frekvencie v rozličných bioenergetických pásmach. In:Telesná výchova a špor, 17, 2007, 3-4. Bratislava: Slovenská vedecká spoločnost' pre telesnú výchovu a šport a Sekcia športu, detí a mládeže MŠ SR, 2007. s. 21-24. ISSN 1335-2245

LÉGER, L. A. \& GADOURY, C. 1989. Validity of the 20 meter shuttle run test with 1 minute stages to predict VO2max in adults. Can. J. Sport Science, 14, 1989, č. 1. s. 21-26. In: MORAVEC, R. \& TOMÁNEK, L..: Závislost' výkonnosti vo vytrvalostnom člnkovom behu od podielu srdcovej frekvencie v rozličných bioenergetických pásmach. In: Telesná výchova a šport, 17, 2007, 3-4. Bratislava: Slovenská vedecká spoločnost' pre telesnú výchovu a šport a Sekcia športu, detí a mládeže MŠ SR, 2007. s. 21-24. ISSN 1335-2245

MĚKOTA, K. \& BLAHUŠ, P. 1983. Motorické testy v tělesné výchově. Praha: SPN. 1983. 335 s.

MORAVEC, R., KAMPMILLER, T. \& SEDLÁČEK, J. a kol. 2002. EUROFIT. Telesný rozvoj a pohybová výkonnost' školskej populácie na Slovensku. 2. vydanie. Bratislava: Slovenská vedecká spoločnost’ pre telesnú výchovu a šport, 2002. 180 s. ISBN 80-89075-11-8

MORAVEC, R. \& TOMÁNEK, L. 2007. Závislost' výkonnosti vo vytrvalostnom člnkovom behu od podielu srdcovej frekvencie $\checkmark$ rozličných bioenergetických pásmach. In: Telesná výchova a šport 17, 2007, 3-4. Bratislava: Slovenská vedecká spoločnost' pre telesnú výchovu a šport a Sekcia športu, detí a mládeže MŠ SR, 2007. s. 21-24. ISSN 1335-2245 
PERÁČEK, P. 1990. Diagnostika herného výkonu mladých futbalistov. Písomná práca ku kandidátskej odbornej skúške. Bratislava: FTVŠ UK, 1990. $36 \mathrm{~s}$.

PERÁČEK, P. 1992. Efektívnost' športovej prípravy mladých futbalistov. Kandidátska dizertačná práca. Bratislava: FTVŠ UK, 1992. $250 \mathrm{~s}$.

PERÁČEK, P. 1995. Vplyv špecifických tréningových podnetov na bioenergetické mechanizmy (režimy) futbalistov. In: Acta Facultatis Physicae Universitatis Comenianae XXXVII. Bratislava: FTVŠ UK, 1995. s. 169-173. 285 s. ISBN 80-223-1002-6

PERÁČEK, P. 1999. Osobitosti športovej prípravy reprezentačných družstiev mládeže SR vo futbale. Habilitačná práca. Bratislava: FTVŠ UK, 1999. $127 \mathrm{~s}$.

PERÁČEK, P. 2007. Analýza zataženia hráča vrcholového futbalu. Prednáška pre poslucháčov UEFA PROFI Licencie. Olomouc: február 2007. Rukopis.25 s.

PERÁČEK, P. \& KUČERA, D. 1987. Faktory motorickej výkonnosti určujúce športový výkon vo futbale. In: HAVLÍČEK, I. et al.: Športová príprava talentovanej mládeže. Zborník Vedecko-metodickej rady SÚV ČSZTV, XIII. Bratislava: Šport, STVV, 1987. s. 126-127.

PERÁČEK, P. \& NINCZ, M. 2011. Vplyv herného tréningu na vybrané ukazovatele herného výkonu mladých hráčov vo futbale. Česká kinantropologie. Roč. 15, č.2 (2011), s. 22-32.

PSOTTA, R. et al. 2006. Fotbal. Kondiční trénink. Praha: Grada Publishing, 2006. 220 s. ISBN 80-247-0821-3

REILLY, T. 2002. An Ergonomics Approach to On-Field Training. In: Insight. The F.A. Coaches Association Journal. Issue 3. Volume 5. London: The Football Association, Summer 2002. s. 40-41.

REILLY, T. 2003. Interpreting the Training Stimuls. In: Insight. The F.A. Coaches Association Journal. Issue 3. Volume 6. London: The Football Association, Summer 2003. s. 46-47.

SAVELSBERGH, G. \& KAMP, J. 2001. Training must be as specific as possible, but not always! In: Insight. The F.A. Coaches Association Journal. Issue 4. Volume 4. London: The Football Association, 2001.

STRUDWICK, T. \& REILLY, T. 2001. Work-rate profiles of elite Premiere League football players. In: Insight. The F.A. Coaches Association Journal. Issue 2. Volume 4. London: The Football Association, 2001. s. 28-29

STRUDWICK, T. 2003. Rest and Recovery Strategies for Elite International youth Players. In: Insight. The F.A. Coaches Association Journal. Issue 3. Volume 6. London: The Football Association, Summer 2003. s. 13.

ŠAJBEN, Z. \& PERÁČEK, P. 1987. Účinnost' tréningového zat'aženia v jednoročnom cykle športového tréningu vo futbale. In: HAVLIIČEK, I. et al.: Športová príprava talentovanej mládeže. Zborník Vedecko-metodickej rady SÚV ČSZTV, XIII. Bratislava: Šport, STVV, 1987. s. 221-222.

TARKOVIČ, Š. 1998. Hodnotenie herného výkonu družstva vo futbale. Projekt dizertačnej práce. Bratislava: FTVŠ UK, 1998. 